\title{
EU CONDITIONALITY AND TRANSITIONAL JUSTICE IN THE FORMER YUGOSLAVIA
}

\begin{abstract}
Iavor Rangelov*
Summary: The countries of the former Yugoslavia inherited a difficult legacy of mass atrocities and human rights abuse from the wars of the 1990s. The European Union's association and accession conditionality with respect to Serbia and Montenegro, Bosnia and Herzegovina, and Croatia incorporates the problem of dealing with war crimes only insofar as it requires full cooperation with the International Criminal Tribunal for the Former Yugoslavia. While transfers of war crimes suspects to The Hague have dominated EU relations with the countries of the Western Balkans, domestic transitional justice mechanisms such as truth-telling inquiries and war crimes trials have been ignored by the international community. However, international justice remains both remote and heavily contested across the region, and is often used to radicalise nationalist sentiments instead of facilitating reconciliation among ethnic communities. The goals of EU conditionality in ex-Yugoslavia - promoting reconciliation and cross-border cooperation - can only be effectively advanced if mechanisms of transitional justice are employed at the national level, articulating truth and rebuilding the rule of law by establishing war crimes accountability from within.
\end{abstract}

The May 2005 decision by European Union foreign ministers to postpone accession talks with Croatia due to Zagreb's failure to hand over General Ante Gotovina to the International Criminal Tribunal for the Former Yugoslavia (ICTY) came as part of a wave of EU pressure for cooperation with the Tribunal across the former Yugoslavia. Despite the fact that Gotovina is now in The Hague, and governments have shown intensified cooperation with the court, ICTY rhetoric continues to be widely rejected across the region. This paper analyses EU association and accession conditionality in the Western Balkans with respect to the legacy of mass atrocities inherited from the wars of the 1990s. First, it examines the current EU political conditionality in Croatia, Serbia and Montenegro, and Bosnia and Herzegovina, which has effectively reduced the war crimes issue to full cooperation with the ICTY. It then turns to the process of transitional justice in the region's post-conflict societies, assess-

\footnotetext{
* Ph.D. candidate, Department of Government (with co-supervision of the Law Department), London School of Economics and Political Science.
} 
ing its tensions and shortcomings. Finally, it argues that EU war crimes conditionality, by focusing exclusively on cooperation with the ICTY, has failed to facilitate the process of rebuilding the rule of law in the former Yugoslavia and to advance the goals of international justice: defusing ethnic tensions and promoting reconciliation in the region.

\section{EU Conditionality in the Western Balkans: Political Criteria and the ICTY}

The EU association and accession conditionality for the Western Balkan countries comprises two sets of criteria. The first are the political, economic and institutional criteria established for all candidate countries by the Copenhagen European Council in 1993; the political criteria were defined as "[the] stability of institutions guaranteeing democracy, the rule of law, human rights and the protection of minorities". ${ }^{1}$ With the exception of "protection of minorities", the Treaty of Amsterdam confirmed these criteria, incorporating them in Articles 6 and 49 of the Treaty on the European Union. ${ }^{2}$ The second set of criteria is specific to the Stabilisation and Association Process (SAP) for South East Europe established by the Commission Communication of 26 May $1999,{ }^{3}$ and includes, inter alia, full cooperation with the ICTY, respect for human and minority rights, the creation of real opportunities for the return of refugees and internally displaced persons, and a visible commitment to regional cooperation. ${ }^{4}$

Cooperation with the ICTY has proved the most difficult issue in the SAP context, and has dominated the EU's external relations agenda with all three countries. The European Council, while affirming that the future of the Western Balkans lies within the EU, has repeatedly insisted that progress towards association and eventual EU accession be conditioned on full cooperation with the ICTY. ${ }^{5}$ In its 2004 Annual Report on the SAP, the Commission concluded that cooperation with the ICTY by countries in the region had generally remained insufficient. ${ }^{6}$ The closer a country moves towards opening accession negotiations, the greater the pressure on it to transfer indicted war crimes suspects to The Hague becomes, with ever more serious consequences for its failure to comply.

\footnotetext{
${ }^{1}$ European Council in Copenhagen, Conclusions of the Presidency, Bull EU 6-1993, Pt. I.13. See also Manfred Nowak, "Human Rights "Conditionality" in Relation to Entry to and Full Participation in the EU' in Phillip Alston with Mara Bustelo and James Heenan (eds), The EU and Human Rights (OUP, Oxford 1999) 691-692.

2 The Amsterdam Treaty of 2 October 1997 entered into force on 1 May 1999.

${ }^{3}$ Commission Communication [1999] COM (1999) 235, Bull EU 5-1999, Pt. 1.3.73.

${ }^{4}$ See European Council Conclusions on Conditionality [1997] Bull EU 4-1997, Pt. 2.2.1.

${ }^{5}$ See e.g., Bull EU 1/2-2003, Pt. 1.6.102; Bull EU 6-2004, Pt. I.7.31.

${ }^{6}$ European Commission 2004 Annual Report [2004] COM (2004) 202/2.
} 
So far, Croatia has made the greatest progress towards membership in the Union. Following the January 2000 parliamentary elections and Stjepan Mesić's election as president of the Republic of Croatia in February 2000, growing consensus on Croatia's European future triggered a rapid development of its relations with the EU. In May 2000, the Commission adopted a Feasibility Report ${ }^{7}$ proposing the opening of negotiations for a Stabilisation and Association Agreement (SAA), which was signed on 29 October 2001 and has been governing EU-Croatia relations prior to accession. ${ }^{8}$ Pending ratification of the SAA, an Interim Agreement was signed and entered into force on 1 March 2002. ${ }^{9}$ In December 2004, the European Council noted that progress was satisfactory and, on the condition that Croatia's remaining ICTY indictee, General Ante Gotovina, would be handed over, it decided to open accession negotiations with Croatia on 17 March 2005. ${ }^{10}$ After intensive last-minute discussions on the country's failure to deliver General Gotovina, the Council decided on 16 March 2005 to postpone the opening of negotiations with Croatia. ${ }^{11}$ While reaffirming its commitment to Croatia's accession to the EU, the Council deferred negotiations until full cooperation with the ICTY was achieved. In October 2005 the EU resumed negotiations with the country after ICTY Chief Prosecutor Carla Del Ponte reported that Croatia was now cooperating fully with the Tribunal. ${ }^{12}$ Two months later, General Gotovina was arrested in the Canary Islands and transferred to The Hague. ${ }^{13}$

News of Croatia's suspended negotiations helped intensify efforts for compliance with ICTY conditionality in both Serbia and Montenegro and Bosnia and Herzegovina. By June 2005, Belgrade had transferred most of its at-large indictees to The Hague or persuaded them to surrender, including Generals Lukić and Pavković, whom it had previously insisted on prosecuting in domestic courts. ${ }^{14}$ After the emergence of a videotape

\footnotetext{
${ }^{7}$ European Commission Flexibility Report [2000] COM (2000) 311.

${ }^{8}$ See the Proposal of the Commission [2001] COM (2001) 371.

${ }^{9}$ Council Decision concerning the signing on behalf of the Community and provisional application of the Interim Agreement on trade and trade related matters between the European Community on the one part, and the Republic of Croatia, on the other [2001] OJ $2001 \mathrm{~L} 330 / 1$.

${ }^{10}$ Bull EU 12-2004, Pts. I.6.14 to I.6.16.

${ }^{11}$ Bull EU 3-2005, Pt. I.5.1.

12 Press Release, Council of the EU 12514/1/05 REV 1 (Presse 241) 4 October 2005.

13 The Guardian reported that the Croatian authorities had supplied ICTY investigators with information leading to the arrest. Shortly after receiving this information, Del Ponte announced that Croatia was cooperating fully with the Tribunal. Ian Traynor and Giles Tremlett, 'Capture of War Crimes Suspect Paves Croatia's Way to EU Entry', The Guardian (London, 9 December 2005).

${ }^{14}$ Ian Traynor, 'Full House for The Hague's War Crimes Unit', The Guardian (London 9 June 2005). See also ICTY Press Releases JP/MOW/957e, 4 April 2005, and JP/MOW/966e, 25 April 2005 <http://www.un.org/icty>
} 
showing Serbian soldiers killing Bosnian Muslims, the government announced plans to hand over Ratko Mladić and Radovan Karadžić, the two men currently heading the ICTY's most-wanted list. ${ }^{15}$ Serbia desperately needs to demonstrate consistent compliance, as the Commission approved a Feasibility Report in May 2005 giving the green light to signing an SAA. ${ }^{16}$ At the time of writing, the EU had terminated negotiations with the country pending the arrest of Mladić. Similarly, in its assessment of progress in Bosnia and Herzegovina, the Commission declared that the requirement of full cooperation with the ICTY, particularly in the case of Republika Srpska, had to be met before it could recommend concluding an SAA. ${ }^{17}$ The External Relations Council reaffirmed this position in January 2005. ${ }^{18}$

\section{Transitional Justice in the Former Yugoslavia}

With EU conditionality focusing exclusively on cooperation with the ICTY, the wider process of transitional justice in the post-conflict societies of former Yugoslavia has been largely ignored by the international community. Domestically, transitional justice has been characterised by a lack of genuine reckoning with the past and the widespread denial of atrocities committed on "our" side of the conflict, as well as persistent ethnic bias in the administration of justice.

Despite differing institutional structures for dealing with the past and a differing balance of victims and perpetrators, there are some important features common to the process of transitional justice in all the post-conflict countries of ex-Yugoslavia. Nowhere is the past confronted openly, in an inclusive process of truth-telling that would involve both state inquiries into the conflicts and personal accounts of them. Domestic war crimes trials fail to address the scale of the atrocities, while courts do not administer even-handed justice to war crimes suspects under their jurisdiction, without regard to ethnic and national affiliation. In this context, inter-ethnic and cross-border relations continue to be jeopardised by mutual grievances and tensions, diminishing the possibility for genuine reconciliation and cooperation across ethnic and national divides.

\footnotetext{
${ }_{15}$ BBC News, 3 June 2005, 'Serbian Leader "Shocked” by Video' <http://www.news.bbc. co.uk>

${ }^{16}$ European Commission Feasibility Report [2005] COM (2005) 476; SEC (2005) 478.

17 Report from the Commission to the Council on the preparedness of Bosnia and Herzegovina to negotiate a Stabilisation and Association Agreement with the European Union [2003] COM (2003) 692.

18 Press Release, Council of the EU 5535/05 (Presse 15) 31 January 2005.
} 


\section{A. State Responsibility for Genocide and Aggression}

In March 1993 Bosnia and Herzegovina instituted proceedings before the International Court of Justice (ICJ) against what was then Yugoslavia, claiming violations of the 1948 Convention on the Prevention and Punishment of the Crime of Genocide. ${ }^{19}$ In its application, Bosnia requested that the Court declare that Yugoslavia, through its agents and surrogates, inter alia, had killed, illegally detained and exterminated citizens of Bosnia and Herzegovina, calling on it to immediately terminate the practice of "ethnic cleansing" and pay reparations. Croatia instituted similar genocide proceedings against Yugoslavia in 1999, seeking to establish liability for ethnic cleansing and extensive destruction of property. ${ }^{20}$ In their applications, both Bosnia and Croatia have also referred to alleged aggression by Yugoslavia in the course of the conflicts. Pending adjudication by the ICJ on the merits of these cases, the disputes articulated in international legal proceedings effectively preclude any constructive engagement by governments in the ex-Yugoslav countries, while contested narratives of genocide and aggression only serve to reinforce ethno-nationalist sentiments in the region.

\section{B. Truth-Telling}

Official efforts aimed at truth-telling have notoriously failed in Serbia, largely because they were motivated by political expediency rather than a genuine will to revisit the past. The Yugoslav Truth and Reconciliation Commission (TRC) was established in 2001 by a decision of thenPresident Vojislav Koštunica, ${ }^{21}$ without public debate or consultation with Parliament. The commission's mandate was to address the causes of the conflicts, as opposed to uncovering new facts about hostilities and atrocities. ${ }^{22}$ The lack of a minority representation, resignations by key members, and scarce resources added to the problems facing the TRC, which ultimately failed to disclose any new information, becoming both dysfunctional and irrelevant by 2003.

While no official war crimes inquiry was ever initiated in Croatia, in the Bosnian Federation the popular belief that truth commissions al-

\footnotetext{
${ }^{19}$ Application of the Convention on the Prevention and Punishment of the Crime of Genocide (Bosnia and Herzegovina v. Yugoslavia (Serbia and Montenegro)), Application, 20 March 1993 <http://www.icj-cij.org/icjwww/idocket/ibhy/ibhyframe.htm>

${ }^{20}$ Application of the Convention on the Prevention and Punishment of the Crime of Genocide (Croatia v. Serbia and Montenegro)), Application, 2 July 1999 <http://www.icj-cij.org/ icjwww/idocket/icry/icryframe.htm>

${ }^{21}$ Official Gazette of the Federal Republic of Yugoslavia, 'Decision on the Establishment of the Truth and Reconciliation Commission' (no. 15/2001, 30 March 2001).

${ }^{22}$ See Truth and Reconciliation Commission, Basic Program Document, 15 January 2002 <http://www.komisija.org/osnova.html>
} 
low war criminals to go unpunished kept the idea of establishing such a body on the shelf despite years of deliberation. ${ }^{23}$ The only truth-telling initiative in Bosnia and Herzegovina remains the Commission for Investigation of the Events in and around Srebrenica between 10 and 19 July 1995 (the Srebrenica Commission), which was established by the National Assembly of Republika Srpska in December 2003. Following significant pressure from High Representative Paddy Ashdown and the concurrent vetting of uncooperative officials, the Commission's October 2004 report admitted to the massacre of more than 7,000 Bosnian Muslims at Srebrenica in 1995, disclosing the locations of 32 previously unknown mass graves. Arguably, this constitutes dramatic progress by the Bosnian Serbs towards acknowledging responsibility. Yet many in the Bosnian-Croat Federation have dismissed the Commission's work as the result of international pressure, without genuine remorse and concern for the victims, thus severely limiting its impact on reconciliation.

\section{Domestic War Crimes Trials}

National judiciaries in ex-Yugoslavia have dealt with the issue of war crimes rather reluctantly, failing to provide accountability for most of the atrocities or justice for the majority of the victims. Five years after the regime change, courts in Serbia have completed only a handful of trials, prosecuting mainly low-level paramilitaries and rank-and-file soldiers, while rejecting the doctrine of command responsibility in principle. A special War Crimes Chamber of the Belgrade District Court began its work in April 2004 with the Ovčara case, concerning the massacre of 290 Croatian civilians captured in a Vukovar hospital in 1991. The success of this and future trials depends on tackling systemic problems such as a lack of adequate witness protection and insufficient vetting of officials in the police and judiciary, as well as the generally reluctant attitude of the public and the government alike. ${ }^{24}$

Croatia has largely failed to deliver even-handed justice, despite the significant number of war crimes cases processed by its courts. There has been a deluge of cases involving war crimes prosecutions of Serbs in absentia, compromising the rule of law through selectivity and bias. Bosnia's local justice record is even bleaker, as politicised judiciaries and ethnic bias preclude any accountability for war crimes. Thus Republika Srpska has conducted only two war crimes trials so far. ${ }^{25}$ Disillusioned

${ }^{23}$ See Mark Freeman, 'Bosnia and Herzegovina: Selected Developments in Transitional Justice' (ICTJ Case Studies Series (2004)) <http://www.ictj.org>

${ }^{24}$ See Mark Freeman, 'Serbia and Montenegro: Selected Developments in Transitional Justice' (ICTJ Case Studies Series (2004)) <http://www.ictj.org>

${ }^{25}$ For the Matanović case, see Humanitarian Law Center (Belgrade) Press Release, 20 March 2005, 'First War Crimes Trial in Republika Srpska' < http://www.hlc.org.yu> 
with the progress of domestic prosecutions, the international administration in Bosnia and Herzegovina has placed its hopes in the recentlyestablished special War Crimes Chamber of the State Court, ${ }^{26}$ which is expected to handle some of the backlog and deal with cases which might be transferred from the ICTY.

\section{Limits of the EU's ICTY Conditionality}

The EU's insistence on ICTY conditionality springs from a conviction that the Tribunal is a key factor in rebuilding the rule of law following armed conflict in the Western Balkans, ending impunity for international crimes and facilitating reconciliation across the region. ${ }^{27}$ As an exercise in international legalism, the ICTY was established with the promise of promoting peace by dismantling the ethno-nationalist ideologies which had been reinforced during the conflicts in ex-Yugoslavia. ${ }^{28}$ An important aspect of the Tribunal's mandate was to punish those individuals who were most responsible for the atrocities, thereby precluding notions of collective responsibility and guilt by association. In this sense, the EU has adopted the view of many international lawyers that "judicialisation" of the truth about individual crimes and perpetrators, delivered in impartial proceedings at the international level, would challenge the region's collectivist ideologies, deter future conflict, and facilitate reconciliation across ethnic divides. ${ }^{29}$

Having functioned for more than a decade, and faced with a 2010 completion strategy, the ICTY has largely failed to live up to its promise of individualising guilt and fostering reconciliation. In Serbia, its mandate of prosecuting those most responsible for excesses in the conflicts is regarded as a collective and disproportional punishment of Serbs, as their numbers in different stages of ICTY proceedings are significantly larger than the total number of Croats, Bosnian Muslims and Kosovo Albani-

The second trial dealing with crimes committed in the Manjača camp is to commence in 2006. B92 News, 15 December 2005, 'War Crimes Suspects Arrested in Republika Srpska' $<$ http://www.b92.net>

${ }^{26}$ Agreement between the High Representative for Bosnia and Herzegovina and Bosnia and Herzegovina on the Establishment of Registry of Section I for War Crimes, Organised Crime, Economic Crime and Corruption of the Criminal and Appellate Divisions of the Court of Bosnia and Herzegovina and the Special Department for War Crimes, Organised Crime, Economic Crime and Corruption of the Prosecutor's Office of Bosnia and Herzegovina (on file with the author).

${ }^{27}$ Report by the Commission on the SAP in South East Europe (n 6).

${ }^{28}$ For a summary of the arguments in favour of international prosecutions, see Antonio Cassese, 'Reflections on International Criminal Justice' (1998) 61 Modern L. Rev. 1.

${ }^{29}$ On the currency of the argument that international justice serves to defuse ethnic tensions, see Jose Alvarez, 'Crimes of States/Crimes of Hate: Lessons from Rwanda' (1999) 24 Yale J. of Int'l L. 365, p. 436. 
ans. Beyond this "ethnic calculus", even moderates in Serbia perceive the fact that Milošević was prosecuted in The Hague, while other major villains of the wars, such as Croatia's Franjo Tudjman, were never indicted, as an attempt to distort the historical record of the last decade and put all the blame on the Serbian side. Instead of facilitating political transition and the process of rebuilding the rule of law by dealing with the past, the ICTY trials have been utilised by nationalist forces to demonstrate the persistent victimisation of Serbs and to radicalise Serbian politics. ${ }^{30}$

Distant and complex, the Tribunal's proceedings often fail to resonate with the local public or provide closure for the victims, even in Bosnia and Herzegovina. Despite its substantial jurisprudence concerning crimes against Bosnian Muslims, it was not until April 2004 that the ICTY Appeals Chamber confirmed, in its judgment in the Krstić case, that genocide had indeed been committed in Srebrenica in $1995 .{ }^{31}$ Some of the practices adopted by the Court, such as accepting guilty pleas or taking mitigating circumstances into account, have been condemned by organisations of victims and their families for compromising justice in the name of expediency. Thus, when the former co-president of Bosnia and Herzegovina, Biljana Plavšić, pleaded guilty, expressing her remorse and calling for reconciliation, the effect of her public apology on Bosnian Muslims was significantly diminished by the plea bargain she had obtained and the lenient sentence that followed. ${ }^{32}$

Finally, Croatia's uneasy cooperation with the Tribunal has produced little reconciliation with the past. The Croatian public's continued perception of convicted war criminals as heroes was made clear when Bosnian Croat general Tihomir Blaškić returned to Croatia after being prosecuted by the ICTY for war crimes committed in Central Bosnia in 1993. Despite the fact that Blaškić was cleared of most of the charges on appeal, the ICTY Appeals Chamber sentenced him to nine years imprisonment for abusing detainees. ${ }^{33}$ The time he had already served in custody was taken into account, allowing Blaškić to return home shortly after judgment was rendered. His arrival at Zagreb Airport in August 2004 was greeted by euphoric crowds singing patriotic wartime hymns, and he was received with honours by the Croatian authorities. The status of a war hero was awarded to Blaškić not because the most serious charges were dropped, but rather despite their being dropped. It is difficult to find

${ }^{30}$ Iavor Rangelov, 'International Law and Local Ideology in Serbia' (2004) 16 Peace Rev. 331, at pp. 331-334.

${ }^{31}$ The Prosecutor v. Radislav Krstić, 19 April 2004, case no. IT-98-33-A, III 5-38.

32 The Prosecutor $v$. Biljana Plavšić, 27 February 2003, case no. IT-00-39\&40/1.

33 The Prosecutor $v$. Tihomir Blaškić, 29 July 2004, case no. IT-95-14-A. 
a better illustration of the widespread denial of ICTY rhetoric in Croatia and the limits of reconciliation in the region. ${ }^{34}$

I have argued elsewhere that the ICTY's failure to aid post-conflict societies in overcoming inter-ethnic distrust and nationalist politics derives from a tension between the liberal individualist bias of international law and the collectivist ideology of ethnic nationalism associated with mass atrocity in the former Yugoslavia. ${ }^{35}$ Liberal international lawyers uphold individual agency and responsibility in an attempt to avoid collective responsibility and guilt by association, ${ }^{36}$ thus prosecuting the top perpetrators and implicitly exonerating ethno-national communities. This international legal paradigm has been criticised for allowing its liberal bias to sideline ethnicity, as is evident in such choices as a "denationalised" bench, ethnic neutrality in handling evidentiary issues, and ignoring local calls for ethnic balance in the trials. ${ }^{37}$

The nature of mass atrocity in an ethnic conflict is, however, more collective than international criminal law is ready to admit. The war crimes, crimes against humanity and crimes of genocide prosecuted by the ICTY were committed mainly by members of one ethnic group against individuals who were targeted precisely because they belonged to a rival ethnic group. ${ }^{38}$ Crimes against humanity are, by definition, committed as part of an attack on a civilian population; ${ }^{39}$ in the wars in former Yugoslavia, this meant attacking civilians from the enemy ethnic community. War crimes were often committed as part of larger campaigns of ethnic cleansing, hence the Tribunal's practice of prosecuting them as crimes against humanity as well. ${ }^{40}$ Finally, the "group" nature of genocide has

${ }^{34}$ Ivan Zvonimir Čičak, 'Heroes and Criminals' in Strategy for Transitional Justice in former Yugoslavia (2005) Belgrade: Humanitarian Law Center, pp. 152-158. More recently, the arrest of General Gotovina provoked nationalist protests and huge press across Croatia. BBC News, 11 December 2005, 'Massive Rally for Croatia Suspect'; BBC News, 9 December 2005, 'Press Show Sympathy for Gotovina', both <http://www.news.bbc.co.uk>

${ }^{35}$ Rangelov (n 30) 334-337. For a critique arguing that liberal legality is not an obstacle to confronting mass atrocity and proposing a collective sanctions approach, see Mark Osiel, 'The Banality of Good: Aligning Incentives against Mass Atrocity' (2005) 105 Columbia L. J. 1751, pp. 1837-1859.

${ }^{36}$ See George Fletcher, 'The Storrs Lectures. Liberals and Romantics at War: The Problem of Collective Guilt' (2002) 111 Yale L. J. 1499.

37 Alvarez (n 29) 436-451.

${ }^{38}$ Rangelov (n 30) 335.

39 Statute of the International Tribunal for the Prosecution of Persons Responsible for Serious Violations of International Humanitarian Law Committed in the Former Yugoslavia since 1991 (adopted 25 May 1993), reprinted in International Tribunal for the Prosecution of Persons Responsible for Serious Violations of International Humanitarian Law Committed in the Former Yugoslavia since 1991: Basic Documents, Sales no. E/F/95.III.PI (hereinafter ICTY Statute), Art 5.

${ }^{40}$ See, for example, the treatment of "murder" in the context of the 1998-1999 Serb attacks on Kosovo Albanians, as both a crime against humanity and a violation of the laws 
been codified in the ICTY Statute itself, which requires the establishment of a special intent to destroy, in whole or in part, a national, ethnic, racial or religious group as such. ${ }^{41}$

If the crimes prosecuted by the ICTY demonstrate a significant collective dimension, their relation to the collectivist ideology of ethnic nationalism cannot be so easily avoided by a liberal insistence on individual criminal responsibility. The salience of group ethnicity in these conflicts persists across the former Yugoslavia, where ICTY proceedings are perceived locally not as punishing individuals, but as punishing the nation. Therefore, the goals of establishing the truth about mass atrocities and achieving closure and reconciliation across ethnic and national divides should also be pursued via transitional justice mechanisms at the national level, as these cannot be as easily rejected by the local public. Domestic truth-telling processes could play an important role in challenging denial by exposing the human dimension of atrocities and triggering shock and empathy with the victims, without risking a priori dismissal as illegitimate. Similarly, domestic war crimes trials could be effective in rebuilding the rule of law from within, since delivering justice counters a culture of impunity while allowing recognition of the victims' suffering where it matters most - in the very institutions that embody the perpetrator community as such.

Instead of using its leverage in the association and accession process to encourage the establishment of local tools for accountability, the EU has adopted an unnecessarily narrow understanding of transitional justice with respect to the former Yugoslavia. ${ }^{42}$ By focusing exclusively on full cooperation with the ICTY, EU conditionality in the Western Balkans may have ignored domestic transitional justice to the detriment of its own purported goals: intensified regional cooperation and respect for the rule of law. Furthermore, had domestic transitional justice processes taken root in each of the relevant countries, the ICTY's chances of fulfilling its praiseworthy mandate of reconciliation would have been greater. Truthtelling and domestic justice may be the conditions which need to obtain first in Serbia and Montenegro, Bosnia and Herzegovina, and Croatia in order for international justice to become locally relevant as intended.

and customs of war, in The Prosecutor v. Slobodan Miloševic et al, Kosovo: Second Amended Indictment, 29 October 2001, case no. IT-99-37-PT, IIII 53-61, 65-66.

${ }^{41}$ ICTY Statute, Art 4(2).

${ }^{42}$ On the wide range of transitional justice mechanisms available to post-conflict societies, see UNGA 'Report of the Secretary General on the Rule of Law and Transitional Justice in Post-Conflict Societies' (2004) UN Doc S/2004/616. 


\section{Conclusion}

Rebuilding the rule of law in the countries of the former Yugoslavia is conditioned on dealing with the difficult legacy of the armed conflicts of the 1990s. The EU's conditionality with respect to Croatia, Bosnia and Herzegovina, and Serbia and Montenegro has narrowly interpreted the Copenhagen political criteria in the SAP, focusing exclusively on full cooperation with the ICTY while ignoring domestic mechanisms for transitional justice. By excluding local truth-telling processes and war crimes trials from its association and accession conditionality, the EU has missed an important opportunity to encourage the region's governments and societies to acknowledge and deal with mass atrocities committed during the conflicts. Ignoring domestic transitional justice processes has allowed the persistence of ethno-nationalist ideologies and denial of responsibility for war crimes, thus obstructing both the process of rebuilding the rule of law and international justice's goal of facilitating lasting peace and reconciliation in the Western Balkans. As the ex-Yugoslav countries move closer to the Union, and the EU's leverage in negotiations increases, taking this lesson seriously might be the key to maximising the impact of EU conditionality as a positive force for transition in the region. 
